\title{
Monitoring natural organic matter and disinfection by-products at different stages in two South African water treatment plants
}

\author{
BB Mamba1*, RW Krause', B Matsebula1 and J Haarhoff ${ }^{2}$ \\ ${ }^{1}$ Department of Chemical Technology, University of Johannesburg, PO Box 17011, Doornfontein, 2028, Johannesburg, South Africa \\ ${ }^{2}$ Department of Civil Engineering Science, University of Johannesburg, PO Box 542, Auckland Park 2006, Johannesburg, South Africa
}

\begin{abstract}
Natural organic matter (NOM) is a complex organic material present in natural surface water. NOM can cause problems during water treatment - most notably the formation of toxic disinfection by-products. This study was undertaken in order to assess the effectiveness of some of the water treatment techniques employed by selected water supply companies in South Africa in dealing with NOM. Total organic carbon (TOC) and ultra violet (UV) absorbance at wavelength of $254 \mathrm{~nm}$ were measured and used to calculate specific ultra violet absorbance (SUVA), which was used to determine the changes in NOM concentration throughout the water treatment train. Other parameters measured include $\mathrm{pH}$, turbidity, chemical oxygen demand (COD) and conductivity. Water samples were collected from two water treatment plants in South Africa, namely Sedibeng (Balkfontein) and Midvaal. The overall TOC reduction after the water treatment processes was $33 \%$ and $30 \%$ at Midvaal and Sedibeng, respectively. SUVA values were generally low $\left(<2 \ell \cdot \mathrm{mg}^{-1} \cdot \mathrm{m}^{-1}\right)$ indicating the presence of aliphatic compounds and less 'aromaticity' in NOM of the water samples. Water insoluble $\beta$-cyclodextrin $(\beta-C D)$ polyurethanes were then applied to the water to compare TOC reduction in addition to 'normal' water treatment processes, and were found to provide up to $19 \%$ additional TOC decrease, and UV absorbance reduction was up to $78 \%$. Results obtained using gas chromatography-mass spectrometry (GC-MS) analysis after chlorination, revealed that the water had the potential to form halomethane compounds with chloroform being the most dominant. Again, water-insoluble $\beta$-CD polyurethanes were applied to the water as a treatment to remove trihalomethanes (THMs) and were found to efficiently remove up to $95 \%$ of THMs formed during the disinfection step. The treatment processes studied have limited ability in dealing with NOM and are not individually effective in NOM removal. Results obtained indicate that the application of $\beta-\mathrm{CD}$ polyurethanes in addition to the water treatment processes may enhance NOM removal in water and significantly reduce the THMs formed.
\end{abstract}

Keywords: $\beta$-cyclodextrin polyurethanes, natural organic matter, total organic carbon

\section{Introduction}

The goal of potable water treatment is primarily to produce drinking water that does not pose any health hazard to humans. During the drinking water treatment processes some microbiological and physiochemical components are removed from the water, or chemicals are added to kill pathogens. Natural organic matter (NOM) is a complex organic material found in natural surface water sources derived primarily from the degradation of plant and microbial residues (Vanloon et al., 2005). NOM is found in sources of drinking water at levels generally between 2 and $15 \mathrm{mg} / \ell$ (Hepplewhite et al., 2004), causing the yellow or brown colour in water. This colouration is aesthetically unpleasant to consumers, but NOM is also an energy source for bacterial re-growth (Moreau, 2006) and can cause other treatment-related problems like the formation of disinfection by-products (DBPs) and resin or membrane fouling. Furthermore, it consumes treatment chemicals and hence increases the cost of treatment. Treatment chemicals also need careful consideration, since NOM can facilitate the transportation of inorganic and organic content due to humic complexation (AWWA, 1990).

The processes and technologies used to remove contaminants from water and to improve water quality are common in many parts of the world. The presence of NOM in water is

\footnotetext{
* To whom all correspondence should be addressed.

営 +2711 559 6516; fax: +2711 5596425 ;

e-mail: bmamba@uj.ac.za

Received 12 November 2008; accepted in revised form 12 January 2009.
}

an important factor in determining the cost and complexity of water treatment. The choice of water treatment processes and their efficiency depend on the characteristics of the water, while balancing the costs of the treatment methods (Richardson, 2007). NOM in raw water that is earmarked for drinking purposes comprises a wide range of organic compounds some of which are susceptible to removal, due to their size, polarity, or reactivity, but most NOM is not easily removed since it is poorly characterised and its composition and impact is not often fully understood. NOM in a body of water can be estimated using dissolved organic carbon (DOC), while its removal has relied on conventional methods such as coagulation, flocculation and sand filtration. However, each of these treatment methods has certain limitations: DOC reduction by coagulation, for example is influenced by the dose and $\mathrm{pH}$ at which coagulation occurs (Van Leeuwen et al., 2005; Qin et al., 2006).

Ozonation has been employed in water treatment for disinfection purposes because of its high oxidation potential. According to the literature, ozone destroys algal taste and odour (Qin et al., 2006). However, ozonation partially degrades NOM to smaller compounds which may themselves be toxic. While ozone is a very strong disinfectant, it does not remain in water for a very long time, thus chlorine is commonly added to protect the water from bacterial re-growth while in the distribution system. Chlorination on its own is a common disinfection method, but aqueous free chlorine can interact with NOM suspended in natural water to form halogenated disinfection by-products (DBPs) such as trihalomethanes (THMs) (Freese and Nozaic, 2004). The presence of various functional groups within NOM (both charged and neutral) can result in a high yield of DBPs during 


\begin{tabular}{|l|c|c|c|}
\hline \multicolumn{4}{|c|}{ TABLE 1 } \\
\hline Quality of acceptable drinking water \\
\hline Property & $\begin{array}{c}\text { Recommended } \\
\text { operational limit }\end{array}$ & $\begin{array}{c}\text { Maximum allowable } \\
\text { for limited duration }\end{array}$ & $\begin{array}{c}\text { Consumption period, } \\
\text { maximum }\end{array}$ \\
\hline ponductivity $\boldsymbol{\mu} \mathbf{S} / \mathbf{m}$ & $<150000$ & $150000-370000$ & 7 years \\
\hline Turbidity NTU & $5.0-9.5$ & $4.0-10.0$ & No limits $^{\text {N }}$ \\
\hline DOC $\mathbf{m g} \cdot \boldsymbol{\ell}^{-\mathbf{1}} \mathbf{C}$ & $<1$ & $1-5$ & No limit $^{\mathrm{d}}$ \\
\hline
\end{tabular}

${ }^{a}$ Limits based on consumption of $2 \ell$ of water per day by a person of mass $70 \mathrm{~kg}$ over a period of 70 years

${ }^{d}$ Process efficiency and risks associated with pathogens

${ }^{e}$ When DOC is deemed of natural origin, the consumption period can be extended

chlorination (Van Leeuwen et al., 2005). These DBPs have been linked epidemiologically to cancers of the lower intestinal tract and adverse birth outcomes (Yang, 2004; Richardson, 2007).

Activated carbon (AC) is also used in water treatment plants and through physical adsorption it removes contaminants especially micro-organic contaminants from water. In the process, AC improves taste, odour and colour associated with organics present in water (Bolto et al., 2004). However, when NOM is adsorbed by $\mathrm{AC}$ it blocks the adsorption sites thus limiting adsorption of other micro-organic pollutants such as 2-methylisoborneol (MIB) (Newcombe et al., 2002).

To control water quality, drinking water quality standards have been developed by the South African National Standards (SANS, 2006) as hown in Table 1.

Recently, water-insoluble cyclodextrin (CD) polyurethanes have been investigated for the removal of a range of organic compounds in water and were found to be efficient at removing these organics to very low concentration levels (parts per billion levels) (Mamba et al., 2007). Cyclodextrins are cyclic oligosaccharides formed by the action of bacterial enzymes on starch and have a hydrophobic interior cavity and a hydrophilic exterior of the cavity. This feature allows for the encapsulating of various organic materials to produce complexes or supramolecular species in aqueous solutions ( $\mathrm{Li}$ and $\mathrm{Ma}, 2000)$. They can either be natural or synthetic, and can be polymerised with complimentary bi-functional monomers such as hexamethylene diisocyanate (HMDI) to produce water-insoluble polyurethanes.

This study was undertaken to investigate the effectiveness of some of the current water treatment processes currently in use at the Midvaal and Sedibeng water treatment plants in the removal of NOM and related disinfection by-products. These two plants were chosen because of their slightly different water treatment regimes and the differing sources and type of raw water. The Midvaal Water Treatment Plant has a plant capacity of $320 \mathrm{M} \ell / \mathrm{d}$ with a registered use of $238 \mathrm{M} \ell / \mathrm{d}$. Its source of water is the Vaal River, a tributary of the Orange River which is stressed by urban development. The treatment processes used include flotation, ozonation, filtration and chlorination. Sedibeng water treatment plant on the other hand has a similar capacity of $360 \mathrm{M} \ell / \mathrm{d}$ but the current flowthrough is on average $160 \mathrm{M} \ell / \mathrm{d}$. The raw water at this plant is also highly eutrophic and contains a large fraction of treated effluent and industrial sources as well as agricultural runoff. The treatment processes used include coagulation, sedimentation, filtration and chlorination. Both of these treatment plants have source water with higher-than-acceptable NOM. Against this background there is a need to analyse the existing technologies and improve or introduce new innovative strategies to reduce or completely remove acceptable amounts of NOM. Consequently, we report on the extent to which current treatment methods can reduce NOM, and introduce the application of $\beta$-CD/HMDI polyurethanes for the removal of NOM and particularly THMs found in water.

\section{Experimental}

\section{Sampling}

Water samples were taken at two water treatment plants, namely Midvaal and Sedibeng. Sampling was done twice in each water treatment plant, from source and after each of the water treatment stage. Finally, samples were taken from the distribution network at Bothaville and Orkney. Two litres of sample were collected in triplicate at each site and stored in the refrigerator at $4^{\circ} \mathrm{C}$, and analysed within $24 \mathrm{~h}$.

\section{Total organic carbon (TOC) analysis}

NOM was quantified in each sample by determining TOC, using an Apollo 900 Tekmar TOC analyser. The samples were filtered through a $0.45 \mu \mathrm{m}$ membrane filter and poured into $40 \mathrm{~m} \ell$ TOC vials with Teflon septum caps for analysis. Potassium hydrogen phthalate (KHP) standard solutions of concentrations of 5, 10, 15 and $20 \mathrm{mg} \cdot \ell^{-1}$ were used to calibrate the instrument and blanks were analysed throughout the process.

\section{Chemical oxygen demand (COD) analysis}

The COD analysis was done at Magalies Water Scientific Services Laboratory. The rationale for the COD test is that nearly all organic compounds can be fully oxidised to carbon dioxide with a strong oxidising agent (potassium dichromate $\left(\mathrm{K}_{2} \mathrm{Cr}_{2} \mathrm{O}_{7}\right)$ ) under acidic conditions, and hence this is a good comparison for the TOC values. The excess $\mathrm{K}_{2} \mathrm{Cr}_{2} \mathrm{O}_{7}$ is then titrated with ferrous ammonium sulphate. An oxidation-reduction indicator (ferroin) is also added during this titration step. Once all the excess dichromate has been reduced, the ferroin indicator changes from blue-green to reddish-brown.

\section{Conductivity, $\mathrm{pH}$, and turbidity analysis}

Conductivity and $\mathrm{pH}$ were measured at $25^{\circ} \mathrm{C}$ using HANNA combo $\mathrm{EC}$ and $\mathrm{pH}$ waterproof meter. The $\mathrm{pH}$ meter was calibrated using $\mathrm{pH} \mathrm{4,} 7$ and 9 buffer solutions. HANNA HI98703 Turbidimeter fast track was used to measure the turbidity of the water samples using purchased calibration solutions of $0.1,15$ and 100 NTU.

\section{UV/Visible and SUVA analysis}

UV absorbance was measured at $254 \mathrm{~nm}$ using a Varian Cary 50 UV/Visible spectrophotometer in a $1 \mathrm{~cm}$ quartz cuvette. Humic acid was used as a standard to represent NOM. The calibration curve was drawn from standard humic acid concentrations of $5,10,15$ and $20 \mathrm{mg} \cdot \ell^{-1}$. 


\begin{tabular}{|l|l|}
\hline \multicolumn{2}{|c|}{$\begin{array}{c}\text { TABLE 2 } \\
\text { GC-MS conditions }\end{array}$} \\
\hline Parameter & Condition \\
\hline Column type & VF,5ms, 30 x $0.25 \mathrm{~mm}, 0.25 \mu \mathrm{m}$ \\
\hline Injector & Splitless, 3 min sample exposure \\
\hline Injector temperature & $200^{\circ} \mathrm{C}$ \\
\hline Oven temperature & $35^{\circ} \mathrm{C}$ (hold for $\left.4 \mathrm{~min}\right) @ 9^{\circ} \mathrm{C} / \mathrm{min}$ and \\
& $120^{\circ} \mathrm{C}$ (hold for 3 min) \\
\hline Ionisation & Electron impact \\
\hline Carrier gas & Helium \\
\hline Flow rate & $1 \mathrm{m \ell} / \mathrm{min}$ \\
\hline Detector & Mass spectrometer (ion trap) \\
\hline Mode & Full Scan $(\mathrm{m} / z=40-650)$ \\
\hline
\end{tabular}

\section{Determination of trihalomethane formation potential (THMFP)}

To determine potential for THM formation during disinfection, water samples were chlorinated with granular chlorine, buffered to a $\mathrm{pH}$ value of 9 using borate buffer, and then incubated for 7 days at $25^{\circ} \mathrm{C}$ to allow the reaction to reach completion. The chlorinated samples were placed in $100 \mathrm{~m} \ell$ glass vials with screw caps. The vials were filled to prevent the trapping of air bubbles inside. Ascorbic acid (30\%) was used to destroy the remaining free active chlorine, and the samples were analysed by Gas Chromatography-Mass Spectrometry (GC-MS) following solid-phase micro-extraction.

\section{Solid-phase micro-extraction (SPME) and GC-MS analysis}

A $10 \mathrm{mg} \cdot \ell^{-1}$ calibration standard was prepared using 2000 $\mu \mathrm{g} \cdot \mathrm{m} \ell^{-1}$ THM calibration mix in methanol purchased from Supelco. THMs in standard solution were extracted using a $100 \mu \mathrm{m}$ polydimethylsiloxane (PDMS) SPME fibre which was conditioned by exposing it to the injector at an analysis temperature of $200^{\circ} \mathrm{C}$ for $30 \mathrm{~min}$. The fibre was then immersed in $10 \mathrm{~m} \ell$ aliquots of each standard solution for $20 \mathrm{~min}$ at $70^{\circ} \mathrm{C}$. To enhance extraction, a PTFE-coated magnetic stirrer was used to constantly stir the water throughout the extraction time. THMs in water samples were extracted the same way as described for standard solutions. After extraction the fibre was then exposed into the GC injector port for $3 \mathrm{~min}$. GC-MS conditions used for analysis are shown in Table 2.

\section{NOM and THMs removal using $\beta-C D / H M D I$ poly- urethanes}

The synthesis of cyclodextrin polyurethanes has been previously reported by $\mathrm{Li}$ and $\mathrm{Ma}$ (2000). In a typical cross-linking reaction $\beta$-cyclodextrin was polymerised with an 8 -fold excess of hexamethylene diisocynate (HMDI) in $N, N$-dimethyl formamide (DMF) to form water-insoluble $\beta$-CD/HMDI polyurethanes. After synthesis the polymer was heated at $156^{\circ} \mathrm{C}$ under vacuum to remove excess DMF and to also open the $\mathrm{CD}$ cavities. Solid phase extraction (SPE) cartridges were loaded with $0.3 \mathrm{~g}$ of the $\beta-\mathrm{CD} / \mathrm{HMDI}$ polymer and then treated with deionised water until the TOC levels were $<1 \mathrm{mg} \cdot \ell^{-1}$ (this removes any un-reacted cyclodextrin). Water samples and chlorinated water samples were then passed through the $\beta-C D / H M D I$ polyurethanes at a filtration rate of $10 \mathrm{~cm}^{3} \cdot \mathrm{min}^{-1}$. The filtrate was then analysed to determine the removal effect of the $\beta-\mathrm{CD}$ polyurethanes on the organic pollutants in the water.

\section{Results and discussion}

\section{NOM removal by water treatment processes}

The efficiency of water treatment processes at two water treatment plants (Midvaal and Sedibeng) was determined by measuring different parameters, i.e. TOC, UV absorbance, SUVA, $\mathrm{COD}$, conductivity, $\mathrm{pH}$, turbidity and THMs, throughout the water treatment train. In principle these treatment processes should reduce these parameters to below the accepted SANS values (Table 1). Tables 3 and 4 (next page) list the water quality parameters at Midvaal and Sedibeng Water Treatment Plants, respectively.

As can be seen from the above tables, there is a general decrease in TOC from raw water to distribution networks. This decrease from 14.53 to $9.73 \mathrm{mg} \cdot \ell^{-1}$ and from 16.14 to $11.25 \mathrm{mg} \cdot \ell^{-1}$ at Midvaaal and Sedibeng, respectively, represents a $33 \%$ reduction in TOC. The values in the network distribution at Sedibeng were higher than the SANS-recommended operational limit $\left(<10 \mathrm{mg} \cdot \ell^{-1}\right)$, and those at Midvaal were slightly higher. It was also noted in water samples from Midvaal that there is a slight increase in TOC after treatment, which may be due to biofilm formation in the distribution pipes. Although a decrease in TOC was observed as the water passes through the water treatment train, some of the treatment processes did not cause a decrease in TOC levels in water; this was noted for example, after sand filtration at Midvaal Water Treatment Plant. The effect of sand filtration can be limited by overloaded or defective filtration units (Obi et al., 2007) which could be one of the contributing factors for the lack of TOC reduction. A slight increase was observed after sedimentation at the Sedibeng Water Treatment Plant. Common problems experienced with simple sedimenters are that the design flow rates are rarely achieved in practice and a certain element of 'short-circuiting' can occur unless construction, operation and maintenance are carefully carried out (WHO, 2000). It has been noted that NOM enables the micro-organisms to grow in the treatment unit or distribution system (Khan et al., 1998). Thus, exposure to light, bacterial growth and degradation on edges of sedimentation tanks when water has been standing for a long time may be the cause for the slight TOC increase.

A TOC reduction of $12 \%$ was observed after coagulation at Midvaal and a probable contributing factor to the low NOM removal could be due to the high $\mathrm{pH}$ value (7.48) which has an effect on NOM removal especially when coagulants are added. The higher the $\mathrm{pH}$ the less the NOM will be removed. For coagulants like ferric salts and aluminium sulphate to function at their optimum a $\mathrm{pH}$ within a range of between 4 and 6 is required (Swartz et al., 2004). TOC reduction of $11 \%$ was also observed after ozonation. Ozone partially degrades NOM by breaking the bonds of the NOM structure and convert organic carbon to biodegradable organic carbon (Selcuk et al., 2007). Also, a low reduction in TOC was also observed after chlorination.

\section{Absorbance at $254 \mathrm{~nm}$ and SUVA}

In the water industry UV absorbance at $254 \mathrm{~nm}$ is generally useful as an indicator for monitoring the concentration of dissolved organic carbon on line once the correlation between DOC and UV254 has been established (Marrow and Minear, 1987). A reduction in the UV absorbance was observed from raw water to treated water, with a range of 0.04 to 0.17 . In both plants, 


\begin{tabular}{|c|c|c|c|c|c|c|c|}
\hline \multicolumn{8}{|c|}{$\begin{array}{c}\text { TABLE 3A } \\
\text { Water quality parameters at Midvaal Water Treatment Plant }\end{array}$} \\
\hline Parameter & $\begin{array}{c}\text { Raw } \\
\text { water }\end{array}$ & $\begin{array}{c}\text { After } \\
\text { flotation }\end{array}$ & $\begin{array}{c}\text { After } \\
\text { sedimen- } \\
\text { tation }\end{array}$ & $\begin{array}{c}\text { After } \\
\text { ozonation }\end{array}$ & $\begin{array}{l}\text { After sand } \\
\text { filtration }\end{array}$ & $\begin{array}{l}\text { After } \\
\text { chlori- } \\
\text { nation }\end{array}$ & $\begin{array}{c}\text { Distribution } \\
\text { network } \\
\text { (Orkney) }\end{array}$ \\
\hline TOC mg $\ell^{-1}$ & 14.53 & 12.03 & 11.76 & 10.40 & 10.54 & 9.19 & 9.73 \\
\hline Absorbance@254 nm & 0.16 & 0.13 & 0.10 & 0.09 & 0.04 & 0.05 & 0.06 \\
\hline SUVA $\ell \cdot \mathrm{mg}^{-1} \cdot \mathrm{m}^{-1}$ & 1.03 & 1.00 & 0.78 & 0.79 & 0.35 & 0.54 & 0.62 \\
\hline pH & 8.85 & 9.12 & 9.00 & 8.92 & 8.40 & 8.21 & 8.07 \\
\hline Conductivity $\mu \mathrm{S}$ & 665 & 683 & 700 & 735 & 733 & 744 & 716 \\
\hline Turbidity NTU & 0.36 & 0.11 & 0.10 & 0.12 & 0.07 & 0.06 & 0.07 \\
\hline COD $\mathrm{mg}^{-1} \mathrm{O}$ & 24.06 & 23.00 & 22.98 & 20.60 & 20.34 & 21.18 & 19.04 \\
\hline THMFP/TOC $\mu \mathrm{g} \cdot \mathrm{mg}^{-1}$ & 112.6 & 96.3 & 91.1 & 99.7 & 92.1 & 129.0 & 120.4 \\
\hline
\end{tabular}

\begin{tabular}{|c|c|c|c|c|c|c|}
\hline \multicolumn{7}{|c|}{$\begin{array}{l}\text { TABLE 3B } \\
\text { Water quality parameters at Sedibeng Water Treatment Plant }\end{array}$} \\
\hline $\begin{array}{l}\text { Water quality parameters } \\
\text { at Sedibeng Water Treat- } \\
\text { ment Plant }\end{array}$ & $\begin{array}{l}\text { Raw } \\
\text { water }\end{array}$ & $\begin{array}{c}\text { After } \\
\text { coagulation }\end{array}$ & $\begin{array}{l}\text { After } \\
\text { sedimen- } \\
\text { tation }\end{array}$ & $\begin{array}{l}\text { After sand } \\
\text { filtration }\end{array}$ & $\begin{array}{c}\text { After } \\
\text { chlorination }\end{array}$ & $\begin{array}{c}\text { Distribution } \\
\text { network } \\
\text { (Bothaville) }\end{array}$ \\
\hline TOC mg $\ell^{-1}$ & 16.14 & 14.15 & 14.27 & 13.54 & 11.43 & 11.25 \\
\hline Absorbance@254 nm & 0.17 & 0.14 & 0.12 & 0.13 & 0.14 & 0.1 \\
\hline SUVA $\ell \cdot \mathbf{m g}^{-1} \cdot \mathbf{m}^{-1}$ & 0.98 & 0.59 & 0.79 & 0.89 & 0.90 & 0.89 \\
\hline pH & 8.59 & 7.48 & 7.86 & 7.99 & 7.79 & 8.00 \\
\hline Conductivity $\mu \mathrm{S}$ & 665 & 695 & 672 & 677 & 691 & 694 \\
\hline Turbidity NTU & 0.26 & 0.10 & 0.14 & 0.13 & 0.13 & 0.08 \\
\hline COD $\mathrm{mg}^{-1} \mathrm{O}$ & 110.73 & 100.51 & 88.85 & 20.08 & 20.17 & 13.28 \\
\hline THMFP/TOC $\mathrm{g}^{\prime} \mathrm{mg}^{-1}$ & 94.98 & 88.24 & 82.90 & 78.98 & 109.54 & 102.87 \\
\hline
\end{tabular}

the SUVA values were generally low $\left(<2 \ell \cdot \mathrm{mg}^{-1} \mathrm{~m}^{-1}\right)$ indicating a low aromatic content of NOM in the water samples. This is in contrast with studies done by Swartz et al. (2004) on South African coloured surface waters whereby the SUVA values were $>2 \ell \cdot \mathrm{mg}^{-1} \cdot \mathrm{m}^{-1}$ because of the low DOC values. This, in fact, confirms our hypothesis of the non-uniformity of South African waters in terms of NOM content and its composition. Notably, there was a decrease in the SUVA values throughout the water treatment train which indicated a decrease in the aromatic component of NOM in the water samples.

\section{COD}

COD is a measure of the oxygen equivalent of organic matter content of a sample that is susceptible to oxidation by a strong chemical oxidant. The COD values ranged between 19.04 and $24.06 \mathrm{mg} \cdot \ell^{-1}$ and between 13.28 and $110.73 \mathrm{mg} \cdot \ell^{-1}$ for the Midvaal and Sedibeng water treatment plants respectively. Raw water COD levels were higher at Sedibeng than at Midvaal and a decrease in the COD levels was observed after each water treatment stage. COD can be related empirically to DOC and is a useful test for monitoring and controlling the amount of organic pollutants found in surface water after correlation with DOC has been established (Swartz et al., 2004). It was observed in both water treatment plants that COD decreases with a reduction in TOC. Noteworthy, a sharp decrease was observed after sand filtration at Sedibeng suggesting that the sand-filtration process removed most of the oxidisable organic matter.

\section{$\mathrm{pH}$}

The $\mathrm{pH}$ of the water samples after each treatment process ranged between 7.48 and 9.12. The $\mathrm{pH}$ at the network distribu- tion ranged between 8.00 and 8.07 , which is within the SANS recommended operational limit and the South African Target Water Quality (SATWQ) limits for no risks (6.00 to $9.00 \mathrm{pH}$ units). Furthermore, $\mathrm{pH}$ has an effect on NOM removal especially when coagulants are added. For instance, at higher $\mathrm{pH}$ values less NOM is removed whereas low $\mathrm{pH}$ promotes the aggregation of organic matter (Weishaar, 2003) making it easy to remove. This is evident with the low TOC reduction after coagulation where the $\mathrm{pH}$ was $>6$.

\section{Conductivity}

The conductivity of the water samples at both water treatment plants ranged between 665 and $744 \mu \mathrm{S}$, which is within the recommended operational standards. It was noted that the conductivity increases as the water passes through the treatment processes. This increase can be associated with the addition of coagulants like ferric chloride, and aluminium sulphate during coagulation and chlorine during chlorination. The presence of inorganic dissolved solids such as chlorides, sulphates, iron and aluminium can increase the conductivity of water (USEPA, 2006).

\section{Turbidity}

Turbidity can limit the effectiveness of chlorine during disinfection (Obi et al., 2007) which may be the result of the low TOC removal observed after chlorination. The turbidity of the water samples varied between 0.06 and 0.26 NTU which fell within with the SANS limits $(<5$ NTU) and was within the SATWQ range $(<1 \mathrm{NTU})$. A decrease in turbidity was observed from raw water to treated water in both water treatment plants. 


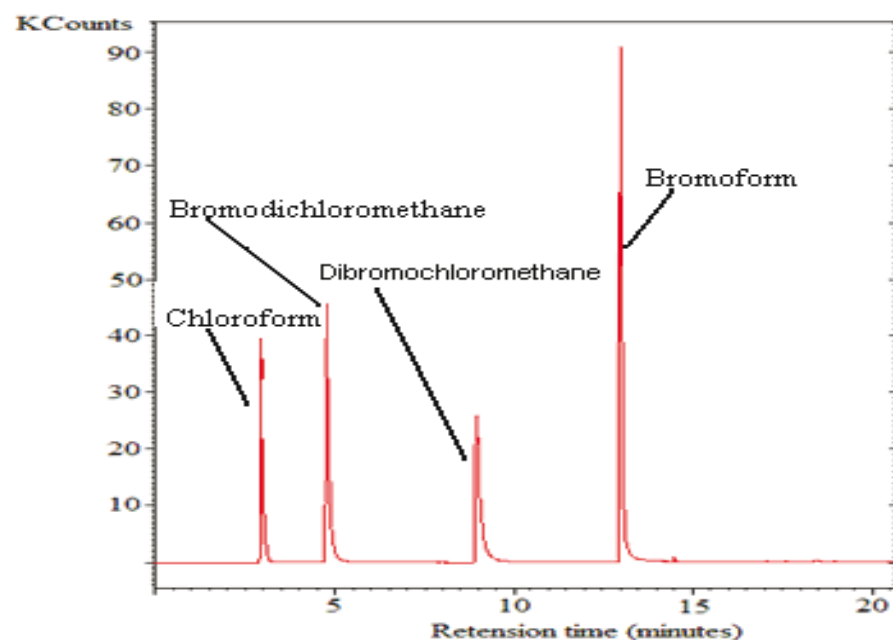

Figure 1

GC-MS chromatogram of $10 \mathrm{mg} \cdot \ell^{-1}$ calibration standard showing peaks of chloroform, bromodichloromethane, dibromochloromethane and bromoform

\section{THM formation potential and THM removal using $\beta-C D / H M D I$ polyurethanes}

Figure 1 shows the GC-MS chromatogram of a $10 \mathrm{mg} \cdot \ell^{-1}$ calibration standard with peaks showing the presence of chloroform, bromodichloromethane, dibromochloromethane and bromoform.

The water samples showed the potential to form THMs, i.e. chloroform and bromodichloromethane in all the different treatment stages. This suggests that there is an inherent link between the presence of NOM and the formation of THMs. Figure 2 shows GC-MS representative chromatograms of THM formation potential of the raw water, and after the water samples had been passed through the water-insoluble $\beta-\mathrm{CD} /$ HMDI polyurethane. The graphs are scaled to the same value for visual comparison only.

The $\beta$-CD/HMDI polyurethane effectively removed THMs in water with a removal efficiency of $95 \%$ based on ion count. These results concur with studies reported by (Mhlanga et al., 2006 and Salipira et al., 2008) which showed that $\beta$-CD polyurethane demonstrated an ability to remove organic pollutants from water by absorbing these pollutants into the cyclodextrin moiety hydrophobic cavities and through general adsorption on the polyurethane substrate, which also acts as a sorbent.

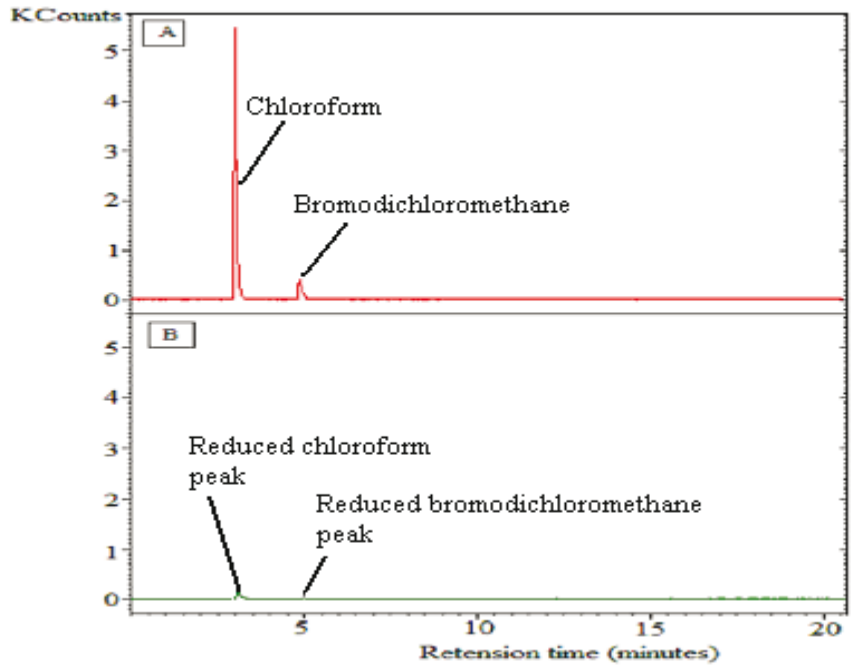

Figure 2

GC-MS chromatograms showing THM formation potential in raw water sample from Midvaal (A) and after passing through $\beta-C D$ polyurethane $(B)$

\section{The effect of $\beta-C D / H M D I$ polyurethanes on TOC and UV absorbance}

The removal efficiency of TOC and UV254 $\mathrm{nm}$ by $\beta$-CD/HMDI polyurethanes are shown in Tables 4 and 5 .

TOC reduction by $\beta$-CD/HMDI polyurethanes on the water coming from each water treatment step was up to $19 \%$. Cyclodextrins have a central cavity that provides an excellent resting site for hydrophobic molecules such as organic compounds. This cavity is non polar and provides a micro environment in which appropriately sized non-polar compounds can be encapsulated to form inclusion complexes ( $\mathrm{Li}$ and $\mathrm{Ma}, 2000)$. The low reduction in TOC could be due to the fact that NOM is not appropriately sized for the formation of inclusion complexes with $\beta-\mathrm{CD} /$ HMDI polyurethanes. However, the $\beta$-CD/HMDI polyurethanes were very effective at reducing the UV absorbance in the water samples, as an up to $78 \%$ reduction was observed. This implies that the $\beta-\mathrm{CD} / \mathrm{HMDI}$ polyurethanes could effectively absorb the aromatic chromophores of NOM measured at $254 \mathrm{~nm}$.

We have previously reported on a comparative study between $\beta$-CD/HMDI polyurethanes and activated carbon in the removal of organic pollutants from water at very low concentration levels $\left(\mathrm{ng} \cdot \ell^{-1}\right)$ (Salipira et al., 2008). The polyurethanes removed pollutants at concentration levels of parts-per-billion and could be recycled at least 18 times while still maintaining their adsorption

TABLE 4

The effect of $\beta-C D / H M D I$ polyurethanes on TOC and UV absorbance on water from the Midvaal Water Treatment Plant

\begin{tabular}{|l|c|c|c|c|c|c|}
\hline $\begin{array}{l}\text { Water treatment } \\
\text { process }\end{array}$ & $\begin{array}{c}\text { Initial } \\
\text { TOC } \\
\left(\mathbf{m g} \cdot \mathbf{\ell}^{-1} \mathbf{)}\right.\end{array}$ & $\begin{array}{c}\text { Final } \\
\text { TOC } \\
\left(\mathbf{m g} \cdot \mathbf{\ell}^{-1} \mathbf{)}\right.\end{array}$ & $\begin{array}{c}\text { TOC } \\
\text { reduction } \\
\mathbf{( \% )}\end{array}$ & $\begin{array}{c}\text { Initial } \\
\text { UV @ } \\
\mathbf{2 5 4} \mathbf{~ n m}\end{array}$ & $\begin{array}{c}\text { Final } \\
\text { UV@ 254 nm }\end{array}$ & $\begin{array}{c}\text { UV } \\
\text { reduction } \\
(\mathbf{\%})\end{array}$ \\
\hline Raw water & 14.53 & 12.27 & 16 & 0.16 & 0.05 & 70 \\
\hline After flotation & 12.03 & 10.68 & 11 & 0.13 & 0.04 & 66 \\
\hline After sedimentation & 11.76 & 10.48 & 11 & 0.10 & 0.03 & 69 \\
\hline After ozonation & 10.40 & 9.37 & 10 & 0.09 & 0.04 & 64 \\
\hline After sand filtration & 10.54 & 8.54 & 19 & 0.04 & 0.01 & 66 \\
\hline After chlorination & 9.19 & 7.81 & 15 & 0.05 & 0.01 & 71 \\
\hline Network distribution & 9.73 & 8.56 & 12 & 0.06 & 0.03 & 57 \\
\hline
\end{tabular}




\begin{tabular}{|c|c|c|c|c|c|c|}
\hline \multicolumn{7}{|c|}{$\begin{array}{c}\text { TABLE } 5 \\
\text { The effect of } \beta-C D / H M D I \text { polyurethanes on TOC and UV absorbance on water from the Sedibeng } \\
\text { Water Treatment Plant }\end{array}$} \\
\hline $\begin{array}{l}\text { Water treatment } \\
\text { process }\end{array}$ & $\begin{array}{c}\text { Initial } \\
\text { TOC } \\
\left(\mathrm{mg} \cdot \mathrm{e}^{-1}\right)\end{array}$ & $\begin{array}{c}\text { Final } \\
\text { TOC } \\
\left(\mathrm{mg} \cdot \mathrm{e}^{-1}\right)\end{array}$ & $\begin{array}{c}\text { TOC } \\
\text { reduction } \\
(\%)\end{array}$ & $\begin{array}{c}\text { Initial } \\
\text { UV @ } \\
254 \text { nm }\end{array}$ & $\begin{array}{l}\text { Final UV@ } \\
254 \text { nm }\end{array}$ & $\begin{array}{c}\text { UV } \\
\text { reduction } \\
(\%)\end{array}$ \\
\hline Raw water & 16.14 & 15.87 & 7 & 0.17 & 0.04 & 75 \\
\hline After coagulation & 14.15 & 13.64 & 8 & 0.14 & 0.03 & 79 \\
\hline After sedimentation & 14.27 & 12.13 & 15 & 0.12 & 0.03 & 79 \\
\hline After sand filtration & 13.54 & 12.71 & 13 & 0.13 & 0.04 & 71 \\
\hline After chlorination & 11.43 & 10.06 & 12 & 0.14 & 0.03 & 78 \\
\hline Distribution network & 11.25 & 10.17 & 10 & 0.11 & 0.03 & 76 \\
\hline
\end{tabular}

efficiency (Mhlanga et al., 2007). Activated carbon was, on the other hand, only effective at removing contaminants present in water at parts-per-million and lost its adsorption effectiveness once saturated with moisture. Its regeneration is costly since it has to be reheated if it were to be reused for further adsorption studies.

\section{Conclusion}

The water samples collected have a relatively high NOM concentration. Although there is a reduction in TOC which is used as a measure of NOM, the treatment processes have limited ability in dealing with NOM and are not individually effective in NOM removal. The SUVA values are generally low, which is an indication of the presence of aliphatic compounds and low aromaticity. The aromatic component of NOM in the water samples decreases from raw water to treated water. The $\beta-\mathrm{CD} / \mathrm{HMDI}$ polyurethanes were effective in absorbing the aromatic constituent of NOM. The chlorinated water samples from both water treatment plants demonstrated that indeed the presence of NOM in water sample leads to formation of THMs. The water-insoluble $\beta$-CD/HMDI polyurethanes used in this study significantly reduced the THMs $(95 \%)$, which is significant when considering that these species can cause ill-health effects. The application of $\beta-C D / H M D I$ polyurethanes may have a huge impact in water treatment in the future due to their ability to reduce a wide range of organic pollutants to very low concentration levels $\left(\mathrm{ng} \cdot \ell^{-1}\right)$ including the carcinogenic THMs. This may eliminate the negative publicity associated with the use of disinfection processes such chlorination which results in high yields of DBPs. Furthermore, the recyclability $\beta-\mathrm{CD} / \mathrm{HMDI}$ polyurethanes can greatly reduce the cost of water treatment.

\section{Acknowledgements}

Funding from the National Research Foundation(NRF), Eskom's Tertiary Education Support Programme (TESP), Mintek/DST Nanotechnology Innovation Centre (NIC) and the University of Johannesburg is gratefully acknowledged.

\section{References}

AMERICAN WATER WORKS ASSOCIATION (AWWA) (1990) FW Pontius (ed.) Water Quality and Treatment ( $4^{\text {th }}$ edn.). McGraw-Hill, New York.

BOLTO B, DIXON D and ELDRIDGE R (2004) Ion exchange for removal of natural organic matter. React. Funct. Polym. 60 171182.

COLLINS MR, AMY GL and KING PH (1985) Removal of organic matter in water treatment. J. Environ. Eng. 11 850-64.
DWAF (1996) South African Water Quality Guidelines: Domestic Uses $\left(2^{\text {nd }}\right.$ edn.). Department of Water Affairs and Forestry, Pretoria, South Africa. 177-179.

DWAF (1998) Quality of Domestic Water Supplies: Assessment Guidelines ( $2^{\text {nd }}$ edn.). Department of Water Affairs and Forestry, Department of Health and Water Research Commission, Pretoria, South Africa. $32 \mathrm{pp}$.

FREESE SD and NOZAIC D J (2004) Chlorine: Is it really so bad and what are the alternatives? Water SA 30 (5) 18-24. http://www.wrc. brg.za/archives/watersa\%20archive/2004/No5-special/30.pdf

HEPPLEWHITE C, NEWCOMBE G and KNAPPE DRU (2004) NOM and MIB, who wins in the competition for activated carbon adsorption sites? Water Sci. Technol. 49 257-265.

KHAN E, BABCOCK RW, SUFFET IH and STENSTORM MK (1998) Biodegradable dissolved organic carbon for indication waste water reclamation plant performance and treated wastewater quality. Water Environ. Res. 70 1033-1040.

KORSHIN GV, LI C. and BENJAMIN MM (1997) Monitoring the properties of natural organic matter through UV spectroscopy: a consistent theory. Water Res. 31 1787-1795.

MAMBA BB, KRAUSE RW, MALEFETSE TJ, SITHOLE SP, SALIPIRA KL, NXUMALO ED (2007) Removal of geosmin and 2-methylisorboneol (2-MIB) in water from Zuikerbosch Treatment Plant (Rand Water) using $\beta$-cyclodextrin (CD) polyurethanes. Water SA 33 (2) 223-227. http://www.wrc.org.za/downloads/watersa/2007 Apr\%2007/2002.pdf

MATILAINEN A, LINDQVIST N, KORHONEN S and TUHKANEN $\mathrm{T}$ (2002) Removal of NOM in the different stages of water treatment process. Environ. Int. 28 457-65.

MARROW CM and MINEAR RA (1987) Use of regression models to link raw water characteristics to trihalomethane concentrations in drinking water. Water Res. 21 41-49.

MOREAU N (2006) Selection of Anionic Exchange Resins for Natural Organic Matter Removal. Water Research Technical Report BTO.042. KIWA.17 pp.

OBI CL, MOMBA MNB, SAMIE A, IGUMBOR JO, GREEN E and MUSIE E (2007) Microbiological, physiochemical and management parameters impinging on the efficiency of small water treatment plants in the Limpopo and Mpumalanga Provinces of South Africa. Water $S A 33$ (2) 229-237. http://www.wrc.org.za/downloads watersa/2007/Apr\%2007/2022.pd

QIN J, HTUN OO M, KEKRE KA, KNOPS F and MILLER P (2006) Impact of coagulation $\mathrm{pH}$ on enhanced removal of natural organic matter in treatment of reservoir water. Sep. Purif. Technol. $49295-$ 298.

RICHARDSON SD, PLEWA MJ, WAGNER ED, SCHOENY R and DEMARINI DM (2007) Occurrence, genotoxicity and carcinogenicity of regulated and emerging disinfection by-products in drinking water: A review and roadmap for research. Mutation Res. 636 178-242.

SALIPIRA KL, MAMBA BB, KRAUSE RW, MALEFETSE TJ and DURBACH SH (2008) Cyclodextrin polyurethanes polymerised with carbon nanotubes for the removal of organic pollutants. Water SA 34 (1) 113-118. http://www.wrc.org.za/downloads watersa/2008/2198.pd 
SOUTH AFRICAN NATIONAL STANDARDS (SANS) (2006) Drinking Water Edition 6.1 http://www.dwaf.gov.za/iwqs/report.htm (accessed 23 January 2009).

SWARTZ CD, MORRISON IR, THEBE T, ENGELBRECHT WJ, CLOETE VB, KNOTT M, LOEWENTHAL RE and KRUGER P (2004) Characterisation and Chemical Removal of Organic Matter in South African Coloured Surface Waters. WRC Report No. 924/1/03. Water Research Commission, Pretoria, South Africa.

TRAINA SJ, NOVAK J and SMECK NE (1990) An ultraviolet absorbance method of estimating the percent aromatic carbon content of humic acids. J. Environ. Qual. 19 151-153.

USEPA (2006) Monitoring and Accessing Water Quality. http://www. epa.gov/volunteer/stream/vms59.htm (Accessed on 10 November 2008).

VAN LEEUWEN J, DALY R. and HOLMES M (2005) Modelling the treatment of drinking water to maximize dissolved organic matter removal and minimize disinfection by-product formation. Desalination 176 81-89.

VANLOON GW (2005) Environmental Chemistry a Global Perspective ( $2^{\text {nd }}$ edn.). Oxford University. 250-270.

WEISHAAR JL, AIKEN GR BERGAMASCHI BA, FARM MS, FUJII R AND MOPPERS K (2003) Evaluation of Specific Ultraviolet Absorbance as an Indicator of the Chemical Composition and Reactivity of Dissolved Organic Carbon. Environ. Sci. Technol. 37 4702-4708.

WHO (2000) Water Treatment, Seminar Pack for Drinking Water Quality. http://www.who.int/water-sanitation-health/dwq/S12.pdf (Accessed on 7 July 2008)

YANG CY (2004) Drinking water chlorination and adverse birth outcomes in Taiwan. Toxicol. 198 249-254. 
Available on website http://www.wrc.org.za ISSN 0378-4738 = Water SA Vol. 35 No. 1 January 2009

ISSN 1816-7950 = Water SA (on-line) 